\title{
TEACHING STRATEGIES IN ONLINE DISTANCE LEARNING ON CRITICAL THINKING SKILLS AND TECHNICAL SKILLS OF THE STUDENTS
}

\author{
April L. Trilles \\ Graduate School, Laguna State Polytechnic University, Santa Cruz, Laguna, Philippines
}

Article DOI: https://doi.org/10.36713/epra7397

DOI No: 10.36713/epra7397

\begin{abstract}
This study conducted to determine the effect of teaching strategies in online distance learning on the critical thinking skills and technical skills of the students of Liliw National High School, Liliw Laguna, specifically sought to answer the following questions. What is the level of teaching strategies in Online Distance Learning in terms of Lecture-Discussion Method/ Virtual Class; Inquiry-based Method; Visualization; Elaboration? What is the level of critical thinking skills of the student in terms of; Alertness; Flexibility; Decision making? What is the level of technical skills of the students in TLE in terms of; Mensuration and Calculation; Use of tool and equipment; Occupational health and safety? Are the teaching strategies in online distance learning have significant effect on the critical thinking skills of the Grade 7 and 8 TLE online students? Are the teaching strategies in online distance learning have significant effect on the technical skills of the students in Liliw National High School, Liliw, Laguna?

The researcher utilized a descriptive design and used the teaching strategies in technology and livelihood education to its effects on the critical thinking skills and technical skills of the students. Respondents are selected forty-five (45) online distance learning students from grade 7 and 8 levels in Liliw, Laguna. Purposive sampling technique was used to get the sample respondents for this study. The scheme was used to ensure that the student-respondents came from Liliw, Laguna. The main source of data of the study is the survey questionnaire prepared by the researcher and the statistical use of simple descriptive statistics such as mean and standard deviation to determine the mean level of the teaching strategies used by the teachers to measure the students' critical thinking and technical skills..

Based on the data gathered the teaching strategies in online distance learning in terms of lecturediscussion methods/ virtual class, inquiry-based method, visualization, and elaboration obtained a grand $(\mathrm{M}=4.27, \mathrm{SD}=0.58)$ which means that the respondents perceived that the level of teaching strategies was always performed. It could be concluded that the teaching strategies used in online distance learning were always perceived by the students on an excellent level.

The level of the critical thinking skills of the students in TLE in terms of alertness, flexibility, and decision making were always and excellently performed and for technical skills of the students in TLE in terms of mensuration and calculation, use of tools and equipment, and occupational health and safety were also resulted always and excellently performed.

The teaching strategies in online distance learning on critical thinking skills as to alertness in terms of lecture-discussion method/virtual class, inquiry-based method and elaboration resulted in significant analysis while in terms of visualization it resulted in not significant analysis. As for the Flexibility in terms of lecture-discussion method/virtual class, visualization and elaboration got the result to the analysis of not significant however in terms of inquiry-based method resulted as to significant analysis. And for decision making in terms of lecture-discussion method/virtual class, visualization and elaboration got also the result
\end{abstract}


to the analysis of not significant and in terms of inquiry-based method resulted as to significant analysis. The result has not sustained the research hypothesis, therefore; the null hypothesis was partially accepted.

In the effect of teaching strategies in the online distance learning on technical skills of the students as to mensuration and calculation and use of tools and equipment in terms of lecture-discussion, visualization and elaboration got the result the analysis of no significant effect and in terms of inquirybased method got the result of the significant analysis. Lastly, as to occupational health and safety in terms of inquiry-based method, visualization and elaboration got the analysis of not significant, and lecturediscussion in the virtual class got the significant analysis. The effect of teaching strategies in online distance learning in terms of technical skills was also partially sustained the research hypothesis. Therefore; the effect of teaching strategies in online distance learning in terms of critical thinking skills and technical skills were both partially accepted.

School and teachers may adapt the results of this study called, "Teaching Strategies in Online Distance Learning on Critical thinking and Technical skills of the Students", to maintain and enhanced the teaching strategies in teaching technology and livelihood education (TLE) to continue preparing for the current situation that our education system is facing today to bring out the best of the students' performance for the benefit of our students and their future.

KEYWORDS: critical thinking skills, online distance learning, ,teaching strategies, technical skills, TLE

\section{INTRODUCTION}

Teaching field learning in a remote modality clearly poses pedagogical and logistical challenges. Variety of potentially successful approaches to remote teaching of topics typically taught in the field, especially in teaching that needs to develop the critical and technical skills of the students. The education systems now a days changed by the pandemic that focused on the learning outcome types most frequently taught in typical field settings and most heavily impacted by modality shift: identification and natural history, field techniques, data collection, and study design.

Freeman et al., (2014), suggested activities and related resources are general rather than specific and may be applicable to a variety of synchronous or asynchronous remote courses that teach such learning outcomes. It assumed that more active and student - centered activities are generally more engaging to students and likely to produce positive outcomes in both face - to - face and remote environments. The challenges to inclusive teaching posed by shifting to distance - learning modalities that were most frequently identified by respondents were technology, student time, less engaging modality, and geography or transportation. A combination of institutional support, such as providing necessary equipment to students, and thoughtful remote course design, such as focusing on activities likely to be effective in a remote environment, may assist students in overcoming these faculty - perceived barriers. An important consideration, expressed is that remote teaching modalities may exacerbate existing inequalities between students, presumably because of correlation between access to technology and socioeconomic class or other factors.

Through this, a study of the teaching strategies in online distance learning has to think of interventions and techniques for the students to cope in this time. It determines problem of modalities coping the challenges in teaching TLE using the critical thinking skills and technical skills in order to find huge opportunities for the learner's despite of the challenges that we are facing at the moment.

\section{OBJECTIVES}

The study aimed to determine the teaching strategies in Online distance learning: its effect to the critical thinking skills of the students of Liliw National High School, Liliw Specifically, and this study intended to answer the following questions;

1. What is the level of teaching strategies in TLE in terms of :

1.1 online distance learning;

1.1.1 lecture discussion method/ virtual class;

1.1.2 inquiry-based method;

1.1.3 visualization; and

1.1.4 elaboration?

2. What is the level of critical thinking skills of the students in TLE in terms of: 2.1 alertness; 
2.2 flexibility; and

2.3 decision making?

3. What is the level of technical skills of the students in TLE in terms of:

3.1 mensuration and calculation;

3.2 use of tool and equipment; and

3.3 occupational health and safety?

4. Are the teaching strategies in online distance learning has a significant effect on the critical thinking skills of the selected grade 7 and 8 students of Liliw National High, Liliw Laguna?

5. Are the teaching strategies in Online distance learning has a significant effect on the technical skills of the selected grade 7 and 8 students of Liliw National High School, Liliw Laguna?

\section{METHODOLOGY}

The respondents of the study were selected grade 7 and 8 online students in Liliw National High School, Liliw, Laguna for school year 2020-2021. The researcher selected a group of subjects for study from a larger group. Purposive sampling technique was used to get the sample respondents for this study. The scheme was used to ensure that the student-respondents came from Liliw Laguna The respondents of the study included the selected forty five (45) online distance learning students, it consists of twenty three from Grade 7 and twenty two Grade 8 of Liliw National High School, Liliw, Laguna

A validated researcher-made questionnaire was used as the major instrument to gather the adequate data and information from the respective subjects of the study. The copies of the questionnaire were multiplied based from the number of the respondents. Then it was administered with confidentiality, the gathered information was transferred in a tally sheet. Subsequently, codes were assigned to each indicator. The encoded data was given to the researcher's statistician for the descriptive analysis. The gathered data was interpreted and presented in textual and tabular forms and appropriate interpretation was made

Mean and standard deviation were used to determine the level of teaching strategies in online distance learning in terms of lecture/discussion, inquiry-based methods, visualization and elaboration on critical thinking skills of the students in terms of alertness, flexibility and decision making and technical skills of the students in terms of mensuration, use of tolls and equipment and occupational health and safety. In the other hand, Minitab 14 was used in computing the data gathered and treated them statistically using Linear Regression Analysis to know if there is a/no significant effect to teaching strategies' in TLE on critical thinking skills and technical skills of the students.

\section{RESULT AND DISCUSSION}

This chapter deals with the presentation, interpretation and analysis of data gathered to answer the sub problem relative to the main problem of this study on strategies on online distance learning on critical thinking and technical skills of the students. This part discusses the findings of the study based on the research questions.

\section{Teaching strategies in online distance learning (ODL)}

Teaching strategies in online distance learning in terms of lecture discussion method/ virtual class, inquiry-based method, visualization and elaboration was treated statistically accompanied by five-point rating scale made by a researcher. The table shows the indicative statement, weighted mean, standard deviation as well as the remarks.

Table 1. Level of Teaching Strategies in Online Distance Learning

\begin{tabular}{lcll}
\hline \multicolumn{1}{c}{ Variables } & Mean & SD & Remarks \\
\hline Lecture Discussion Method/ & 4.23 & 0.53 & Always \\
Virtual Class & 4.35 & 0.56 & Always \\
Inquiry-based Method & 4.30 & 0.60 & Always \\
Visualization & 4.18 & 0.62 & Often \\
Elaboration & $\mathbf{4 . 2 7}$ & $\mathbf{0 . 5 8}$ & Always \\
$\quad$ Grand Mean/SD & & Excellent \\
\hline
\end{tabular}


Legend:

$\begin{array}{llll}\text { Scale } & \text { Range } & \text { Remarks } & \text { Interpretation } \\ 5 & 4.20-5.00 & \text { Always } & \text { Excellent } \\ 4 & 3.40-4.19 & \text { Often } & \text { Very Satisfactory } \\ 3 & 2.60-3.39 & \text { Sometimes } & \text { Satisfactory } \\ 2 & 1.80-2.59 & \text { Rarely } & \text { Fair } \\ 1 & 1.0-1.79 & \text { Never } & \text { Poor }\end{array}$

Table 1 shows the level of teaching strategies is based on lecture discussion method/ virtual class $(\mathrm{M}=4.23, \mathrm{SD}=0.53)$, inquiry-based method $(\mathrm{M}=4.35, \mathrm{SD}=0.56)$, visualization $(\mathrm{M}=4.30, \mathrm{SD}=0.60)$ and elaboration $(\mathrm{M}=4.18, \mathrm{SD}=0.62)$. It could be gleaned from the table that the level of teaching strategies obtained a grand $(\mathrm{M}=4.27, \mathrm{SD}=0.58)$ which means that the respondents perceived that the level of teaching strategies were always performed. It could be concluded that the teaching strategies used in online distance learning was always perceived by the students on an excellent level.

Table 2. Level of Teaching Strategies in Online Distance Learning in Terms of Lecture Discussion Method/Virtual Class

\begin{tabular}{|c|c|c|c|}
\hline STATEMENT & Mean & SD & Remarks \\
\hline $\begin{array}{l}\text { My teacher was able to: } \\
\text { 1. Encourage us to brainstorm ideas for learning } \\
\text { contracts with their online peers as well as } \\
\text { negotiate the final contract with the instructor } \\
\text { through email or online conferencing. }\end{array}$ & 4.32 & 0.52 & Always \\
\hline $\begin{array}{l}\text { 2. Execute short lectures provide enough } \\
\text { information to serve as a basis for further reading, } \\
\text { research, or other learning activities. }\end{array}$ & 4.22 & 0.56 & Always \\
\hline $\begin{array}{l}\text { 3. Place lecture notes, with links to related } \\
\text { resources and other Web sites embedded in them, } \\
\text { on a web page for the learners to review. }\end{array}$ & 4.24 & 0.48 & Always \\
\hline $\begin{array}{l}\text { 4. Offer continuous feedback regarding progress } \\
\text { toward accomplishing learning objectives } \\
\text { especially in the laboratory in TLE. }\end{array}$ & 4.20 & 0.55 & Always \\
\hline $\begin{array}{l}\text { 5. Have online lectures that could make our lesson } \\
\text { be shorter and more to the point than lectures in } \\
\text { live classrooms which often extend far beyond the } \\
\text { attention span of the audience. }\end{array}$ & 4.20 & 0.50 & Always \\
\hline $\begin{array}{c}\text { Grand Mean/SD } \\
\text { Verbal interpretation }\end{array}$ & 4.23 & 0.53 & $\begin{array}{c}\text { Always } \\
\text { Excellent }\end{array}$ \\
\hline
\end{tabular}

It can be seen from the table, statement no. 1 " encourage us to brainstorm ideas for learning contracts with their online peers as well as negotiate the final contract with the instructor through email or online conferencing" gained the highest $(\mathrm{M}=4.32, \mathrm{SD}=0.52)$. Next is statement no. 2 "Execute short lectures provide enough information to serve as a basis for further reading, research, or other learning activities" $(\mathrm{M}=4.22$, $\mathrm{SD}=0.56)$. Statement no. 3 "Place lecture notes, with links to related resources and other Web sites embedded in them, on a web page for the learners to review" $(\mathrm{M}=4.24, \mathrm{SD}=0.48)$. However, statement no. 4 offering continuous feedback regarding progress toward accomplishing learning objectives especially in the laboratory in TLE" and statement no. 5 "having online lectures that could make our lesson be shorter and more to the point than lectures in live classrooms which often extend far beyond the attention span of the audience" both got (M= 4.20, $\mathrm{SD}=0.50$ ) which means that indicates that teachers got the remark of always and interpreted as excellent in engaging on it respectively. This meant that amidst the pandemic, teachers were able to show their competency in teaching in terms of lecture discussion method during virtual class. 


\section{EPRA International Journal of Research and Development (IJRD)}

Table 3. Level of Teaching Strategies in Online Distance Learning in terms of Inquiry-based Method

\begin{tabular}{|c|c|c|c|}
\hline STATEMENT & Mean & SD & Remarks \\
\hline \\
\hline $\begin{array}{l}\text { 1. Compose small groups' differing ability levels } \\
\text { and use a variety of learning activities to master } \\
\text { material initially developed by my teacher. }\end{array}$ & 4.34 & 0.47 & Always \\
\hline $\begin{array}{l}\text { 2. Create forum for us to discuss more of our topic } \\
\text { especially in the specific topic like mensuration } \\
\text { and calculation. }\end{array}$ & 4.27 & 0.63 & Always \\
\hline $\begin{array}{l}\text { 3. Find convenient and effective way to understand } \\
\text { the online class by means of collaborative } \\
\text { activities in such TLE activities in technical } \\
\text { activities. }\end{array}$ & 4.37 & 0.62 & Always \\
\hline $\begin{array}{l}\text { 4. Internalize the knowledge and skills acquired } \\
\text { from tasks. }\end{array}$ & 4.46 & 0.55 & Always \\
\hline $\begin{array}{l}\text { 5. Allow time for us to socialize and incorporate an } \\
\text { icebreaker. }\end{array}$ & 4.32 & 0.52 & Always \\
\hline $\begin{array}{c}\text { Grand Mean/SD } \\
\text { Verbal interpretation }\end{array}$ & 4.35 & 0.56 & $\begin{array}{c}\text { Always } \\
\text { Excellent }\end{array}$ \\
\hline
\end{tabular}

Table 3 above shows the level of teaching strategies in Online Distance Learning in terms of inquirybased method statement no. 1 "Compose small groups' differing ability levels and use a variety of learning activities to master material initially developed by the teacher" as shown with $(\mathrm{M}=4.34, \mathrm{SD}=0.47)$. Statement no. 2, "Create forums for us to discuss more of our topic especially in the specific topic like mensuration and calculation" with $(\mathrm{M}=4.27, \mathrm{SD}=0.63)$. Statement no. 3, "Find convenient and effective way to understand the online class by means of collaborative activities in such TLE activities in technical activities" got ( $M=4.37$, $\mathrm{SD}=0.62)$. Statement no. 4, "Internalize the knowledge and skills acquired from tasks" got $(\mathrm{M}=4.46, \mathrm{SD}=0.55)$ and statement no. 5 "the teacher allow time for us to socialize and incorporate an icebreaker" with $\mathrm{M}=4.32$, $\mathrm{SD}=0.52$ ). The Grand mean of the table 3 resulted with $\mathrm{M}=4.35, \mathrm{SD}=0.56$ ) with a remark of always with verbal interpretation of excellent. The result implies that the students perceived the teacher's performed excellently amidst pandemic in terms of inquiry based method.

Table 4. Level of Teaching Strategies in Online Distance Learning in Terms of Visualization

\begin{tabular}{|c|c|c|c|}
\hline STATEMENT & Mean & SD & Remarks \\
\hline $\begin{array}{l}\text { My teacher was able to: } \\
\text { 1. Explain what's written on our module for } \\
\text { further understanding. }\end{array}$ & 4.10 & 0.66 & Often \\
\hline $\begin{array}{l}\text { 2. Teach natural and logical that you choose } \\
\text { colorful and funny images over charts and tables. }\end{array}$ & 4.34 & 0.68 & Always \\
\hline $\begin{array}{l}\text { 3. Combine them with the shapes and tools that are } \\
\text { provided by the virtual classroom's software to } \\
\text { organize your lesson. }\end{array}$ & 4.29 & 0.45 & Always \\
\hline $\begin{array}{l}\text { 4. Draw from the news, social media, and any } \\
\text { other source you see fit to complete the lesson's } \\
\text { content. }\end{array}$ & 4.46 & 0.59 & Always \\
\hline $\begin{array}{l}\text { 5. Involve the learners by jointly creating a } \\
\text { presentation on a topic by using the virtual } \\
\text { classroom's additional screens as slides in the } \\
\text { PowerPoint presentation. }\end{array}$ & 4.29 & 0.51 & Always \\
\hline $\begin{array}{c}\text { Grand Mean/SD } \\
\text { Verbal interpretation }\end{array}$ & 4.30 & 0.60 & $\begin{array}{c}\text { Always } \\
\text { Excellent }\end{array}$ \\
\hline
\end{tabular}




\section{EPRA International Journal of Research and Development (IJRD)

Table 4 presents the level of teaching strategies in Online Distance Learning in terms of Visualization. Statement no. 1 "The teacher explains what's written on our module for further understanding" resulted as $(\mathrm{M}=4.10, \mathrm{SD}=0.66)$ interpreted as often. Statement no. 2 that the teacher Teach natural and logical that you choose colorful and funny images over charts and tables with of $\mathrm{M}=4.34, \mathrm{SD}=0.68$ ). Statement no. 3 "Combine them with the shapes and tools that are provided by the virtual classroom's software to organize your lesson" with $(\mathrm{M}=4.29, \mathrm{SD}=0.45)$. Statement no 4 "Draw from the news, social media, and any other source you see fit to complete the lesson's content" got $(\mathrm{M}=4.46, \mathrm{SD}=0.59)$. Statement no. 5, "teacher Involve the learners by jointly creating a presentation on a topic by using the virtual classroom's additional screens as slides in the PowerPoint presentation" got $(\mathrm{M}=4.29, \mathrm{SD}=0.51)$. Statements 2, 3, 4, 5 got the remarks of always verbal interpretation of excellent. To sum up the weighted mean, it resulted as $(\mathrm{M}=4.30, \mathrm{SD}=0.60)$ with the remark always and verbal interpretation of excellent. This indicates that teachers were able to demonstrate their competency in teaching in terms of lecture discussion method during virtual class.

Table 5. The Level of Teaching Strategies in Online Distance Learning in Terms of Elaboration

\begin{tabular}{llll}
\hline \multicolumn{1}{c}{ STATEMENT } & Mean & SD & Remarks \\
\hline $\begin{array}{l}\text { My teacher was able to: } \\
\begin{array}{l}\text { 1. Keep our lessons short, with explanations clear- } \\
\text { cut and concise but with better understanding. }\end{array}\end{array}$ & 4.20 & 0.55 & Always \\
$\begin{array}{l}\text { 2. Divided, and pre-assigned or auto-assigned into } \\
\text { smaller groups for more focused discussions on a } \\
\text { particular topic. }\end{array}$ & 4.29 & 0.67 & Always \\
$\begin{array}{l}\text { 3. Integrate lesson to my daily living. } \\
\begin{array}{l}\text { 4. Reconstruct more meaningful knowledge in her } \\
\text { teaching TLE. }\end{array}\end{array}$ & 4.17 & 0.62 & Often \\
$\begin{array}{l}\text { 5. Initiates questions that, developed through steps } \\
\text { of investigations, attained to conclusion on certain } \\
\text { phenomena in such topic in TLE. }\end{array}$ & 4.24 & 0.58 & Often \\
$\quad \begin{array}{l}\text { Grand Mean/SD } \\
\text { Verbal interpretation }\end{array}$ & $\mathbf{4 . 1 8}$ & $\mathbf{0 . 6 2}$ & Always \\
\hline
\end{tabular}

Table 5 presents the Level of Teaching Strategies in Online distance learning in Terms of Elaboration. The statements are as follows: Statement no 1, "The teachers keep our lessons short, with explanations clear-cut and concise but with better understanding" got $(\mathrm{M}=4.20, \mathrm{SD}=0.55)$ with remarks of always. Statement no. 2 , "Divided, and pre-assigned or auto-assigned into smaller groups for more focused discussions on a particular topic got $(\mathrm{M}=4.29, \mathrm{SD}=0.67)$ also remarks as always. The statement no. 3 the teacher integrate lesson to the students daily living with the $(\mathrm{M}=4.17, \mathrm{SD}=0.62)$ and remarks of often. Statement no. 4, "Reconstruct more meaningful knowledge in her teaching TLE" $(\mathrm{M}=4.00, \mathrm{SD}=0.58)$ with remarks of often. Statement no. 5, "Initiates questions that, developed through steps of investigations, attained to conclusion on certain phenomena in such topic in TLE", $(\mathrm{M}=4.24, \mathrm{SD}=0.62)$ and remarks of always. The overall weighted mean resulted as 4.18 , standard deviation of 0.62 with often remarks and verbal interpretation of very satisfactory. This specifies that the teachers were able to show their competency in teaching in terms of elaboration in method during virtual class.

\section{Level of Critical Thinking Skills}

The level of Critical thinking skills in terms of alertness, flexibility and decision making were treated statistically using the weighted mean and standard deviation accompanied by a five-point rating scale. The table shows the indicative statement, weighted mean, standard deviation and remarks. 
Table 6. Level of Critical Thinking Skills of the Students in TLE in terms of Alertness

\begin{tabular}{llll}
\hline \multicolumn{1}{c}{ STATEMENT } & Mean & SD & Remarks \\
\cline { 2 - 4 } $\begin{array}{l}\text { As a Students, I am able to: } \\
\begin{array}{l}\text { 1. Learn experiences such as field trips, role } \\
\text { playing, model building, assembling objects, }\end{array}\end{array}$ & 0.75 & Often \\
games, and other physical activities are my \\
$\begin{array}{l}\text { interest. } \\
\begin{array}{l}\text { 2. Prefer to do things with a well-structured and } \\
\text { attainable plan. }\end{array}\end{array}$ & 3.95 & 0.70 & \\
$\begin{array}{l}\text { 3. Consult consistently on facts rather than } \\
\text { subjective opinions on decision making. }\end{array}$ & 4.02 & 0.68 & Often \\
$\begin{array}{l}\text { 4. Resolve group conflicts. } \\
\text { 5. I can resolve group conflicts. }\end{array}$ & 3.98 & 0.68 & Often \\
\hline $\begin{array}{l}\text { Grand Mean/SD } \\
\text { Verbal interpretation }\end{array}$ & 3.88 & -.71 & $\begin{array}{l}\text { Often } \\
\text { Often }\end{array}$ \\
\hline
\end{tabular}

Table 6 presents the level of critical thinking skills of the students in TLE in terms of Alertness. Statement no. 1, "The students learn experiences such as field trips, role playing, model building, assembling objects, games, and other physical activities are my interest" got $(\mathrm{M}=3.85, \mathrm{SD}=0.75)$. Statement no. 2, "Prefer to do things with a well-structured and attainable plan" got $(\mathrm{M}=3.95, \mathrm{SD}=0.70)$. Statement no. 3, "Consult consistently on facts rather than subjective opinions on decision making" got ( $\mathrm{M}=4.02 ; \mathrm{SD}=0.68)$. Statement no. 4, "Resolve group conflicts with $(\mathrm{M}=3.98, \mathrm{SD}=0.68)$. And lastly statement no. 5, "the students were able to resolve the group conflict" with $(\mathrm{M}=3.88, \mathrm{SD}=-.71)$. The grand weighted mean resulted as $3.94 ; \mathrm{SD}=0.71$ with overall remark of often and verbal interpretation of very satisfactory. This meant that amidst the pandemic, students were able to show apparently their critical thinking skills in terms alertness.

Table 7. Level of Critical Thinking Skills of the Students in TLE in terms of Flexibility

\begin{tabular}{|c|c|c|c|}
\hline STATEMENT & Mean & SD & Remarks \\
\hline $\begin{array}{l}\text { As a Students, I am able to: } \\
\text { 1. Do things independently. }\end{array}$ & 4.29 & 0.59 & Always \\
\hline $\begin{array}{l}\text { 2. Have a huge interest in interpersonally- } \\
\text { oriented careers like teaching, counselling, social } \\
\text { work, politics or managerial jobs. }\end{array}$ & 4.32 & 0.56 & Always \\
\hline $\begin{array}{l}\text { 3. Use to handle, touch or manipulate on what is } \\
\text { to be learned. }\end{array}$ & 4.51 & 0.55 & Always \\
\hline $\begin{array}{l}\text { 4. Have the ability to switch between thinking } \\
\text { about two different concepts or to think about } \\
\text { multiple concepts simultaneously. }\end{array}$ & 4.41 & 0.62 & Always \\
\hline 5. Strive for my future. & 4.32 & 0.52 & Always \\
\hline $\begin{array}{c}\text { Grand Mean/SD } \\
\text { Verbal interpretation }\end{array}$ & 4.37 & 0.58 & $\begin{array}{c}\text { Always } \\
\text { Excellent }\end{array}$ \\
\hline
\end{tabular}

Table 7 shows the result of the level of critical thinking skills of the students in TLE in terms of flexibility, the stamen are as follows: The students do the thing independently, $(\mathrm{M}=4.29, \mathrm{SD}=0.59)$; The students have a huge interest in interpersonally-oriented careers like teaching, counselling, social work, politics or managerial jobs, $(\mathrm{M}=4.32, \mathrm{SD}=0.56)$; the students use to handle, touch or manipulate on what is to be learned, $(\mathrm{M}=4.51, \mathrm{SD}=0.55)$; have the ability to switch between thinking about two different concepts or to think about multiple concepts simultaneously, $(\mathrm{M}=4.41, \mathrm{SD}=0.62)$; and the students strive for their future with $(\mathrm{M}=4.32, \mathrm{SD}=0.52)$. The overall weighted mean is 4.37 and $\mathrm{SD}$ of 0.58 with remarks of always and overall verbal interpretation of excellent. This indicates that in online distance learning, students were able to display their flexibility competency in the level of critical thinking skills. 
Table 8. Level of Critical Thinking Skills of the Students in TLE in terms of Decision Making

\begin{tabular}{|c|c|c|c|}
\hline STATEMENT & Mean & SD & Remarks \\
\hline $\begin{array}{l}\text { As a Students, I am able to: } \\
\text { 1. Enjoy working with numbers and equations. }\end{array}$ & 4.27 & 0.50 & Always \\
\hline $\begin{array}{l}\text { 2. Remember information through numbers, } \\
\text { sequence and patterns. }\end{array}$ & 4.29 & 0.45 & Always \\
\hline $\begin{array}{l}\text { 3. Have high interest in courses like computer } \\
\text { technology. }\end{array}$ & 4.51 & 0.50 & Always \\
\hline $\begin{array}{l}\text { 4. Reading and writing, and comprehension gives } \\
\text { me a sort of enjoyment more than anything else. }\end{array}$ & 4.46 & 0.50 & Always \\
\hline $\begin{array}{l}\text { 5. Explore and investigate issues related to our } \\
\text { present situation. }\end{array}$ & 4.20 & 0.45 & Always \\
\hline $\begin{array}{c}\text { Grand Mean/SD } \\
\text { Verbal interpretation }\end{array}$ & 4.35 & 0.50 & $\begin{array}{l}\text { Always } \\
\text { Excellent }\end{array}$ \\
\hline
\end{tabular}

Table 8 shows the result on the level of critical thinking skills of the students in TLE in terms of decision making. Statement no. 1, "The students were able to enjoy working with numbers and equations", got $(\mathrm{M}=4.27, \mathrm{SD}=0.50)$. Statement no. 2, "Remember information through numbers, sequence and patterns" with $(\mathrm{M}=4.29, \mathrm{SD}=0.45)$. Statement no. 3, "The students have high interest in courses like computer technology", with $(\mathrm{M}=4.51, \mathrm{SD}=0.50)$.Statement no. 4, "Reading and writing, and comprehension gives me a sort of enjoyment more than anything else", with $(\mathrm{M}=4.46, \mathrm{SD}=0.50)$. Lastly statement no. 5, "Explore and investigate issues related to our present situation" with $(\mathrm{M}=4.20, \mathrm{SD}=0.45)$. The overall grand mean of 4.35 , Standard deviation of 0.50 with remarks of always and verbal interpretation of excellent. The result indicates students were able to show their critical thinking skills in terms of decision making.

\section{Level of Technical Skills}

The level of technical skills of the Students in TLE in terms of Mensuration and Calculation, use of tools and equipment and occupational health and safety were treated statistically. The table shows indicative statement, weighted mean, standard deviation and remarks.

Table 9. Level of Technical Skills of the Students in Online Distance Learning in terms of Mensuration and Calculation

\begin{tabular}{|c|c|c|c|}
\hline STATEMENT & Mean & SD & Remarks \\
\hline $\begin{array}{l}\text { As a Students, I am able to: } \\
\text { 1. Perform measuring certain distance, time and } \\
\text { mass needed for TLE subjects. }\end{array}$ & 4.59 & 0.49 & Always \\
\hline 2. Understand the different types of measuring. & 4.37 & 0.53 & Always \\
\hline $\begin{array}{l}\text { 3. Share my knowledge in identifying the } \\
\text { measure of materials used in cooking. }\end{array}$ & 4.37 & 0.53 & Always \\
\hline $\begin{array}{l}\text { 4. Know the conversion of size e.g. meter to } \\
\text { centimeter. }\end{array}$ & 4.20 & 0.55 & Always \\
\hline 5. Put the amount of the thing into numbers. & 4.17 & 0.49 & Often/ \\
\hline $\begin{array}{c}\text { Grand Mean/SD } \\
\text { Always }\end{array}$ & 4.34 & 0.54 & $\begin{array}{c}\text { Always } \\
\text { Excellent }\end{array}$ \\
\hline
\end{tabular}

Table 9 above shows the level of technical skills of the students in TLE in terms of mensuration and calculation the statements are as follows: statement no. 1, "The students were able to perform measuring certain distance, time and mass needed for TLE subject" resulted the $(\mathrm{M}=4.59, \mathrm{SD}=0.49)$; statement no. 2, "the students understand the different types of measuring" with the $(\mathrm{M}=4.37, \mathrm{SD}=0.53)$ same with the statement number three that the students were able to share knowledge in identifying the measure of materials used in cooking. Statement no. 4, "The students know the conversion of e.g. meter to centimeter" with a $(\mathrm{M}=4.20, \mathrm{SD}=$ $0.55)$. Lastly statement no. 5, "The student put the amount of a thing into numbers" with the (M=4.17, .The overall weighted mean resulted with 4.34, standard deviation 0.54, remarks of always and verbal interpretation 


\section{EPRA International Journal of Research and Development (IJRD)}

Volume: 6 | Issue: 6 | June 2021

- Peer Reviewed Journal

of excellent. The result indicates that the respondents in online distance learning were able to show their technical skills in the mensuration and calculation.

Table 10. Level of Technical Skills of the Students in TLE in terms of Use of Tools and Equipment

\begin{tabular}{|c|c|c|c|}
\hline STATEMENT & Mean & SD & Remarks \\
\hline $\begin{array}{l}\text { As a Students, I am able to: } \\
\text { 1. Identify the tools in the specific activity in TLE. }\end{array}$ & 4.51 & 0.59 & Always \\
\hline $\begin{array}{l}\text { 2. Use the tool properly with the help of my } \\
\text { teacher }\end{array}$ & 4.59 & 0.54 & Always \\
\hline 3. Demonstrate the uses of the tools in TLE. & 4.46 & 0.63 & Always \\
\hline $\begin{array}{l}\text { 4. Use mixing bowl in proper stroke of its } \\
\text { function. }\end{array}$ & 4.29 & 0.51 & Always \\
\hline $\begin{array}{l}\text { 5. Arrange the kitchen utensils according to its } \\
\text { function accordingly. }\end{array}$ & 4.41 & 0.54 & Always \\
\hline $\begin{array}{c}\text { Grand Mean/SD } \\
\text { Verbal Interpretation }\end{array}$ & 4.45 & 0.57 & $\begin{array}{l}\text { Always } \\
\text { Excellent }\end{array}$ \\
\hline
\end{tabular}

The table 10 above result shows that the students were able to identify tools in the specific activity in TLE $(M=4.51, \mathrm{SD}=0.59)$. The second statement stated that the student makes use of tool properly with the help of their teacher resulted of $(\mathrm{M}=4.59, \mathrm{SD}=0.54)$. The student demonstrates the uses of tools in TLE got the $(\mathrm{M}=4.46, \mathrm{SD}=0.63)$. The student used mixing bowl in proper stroke of its function, with $(\mathrm{M}=4.29, \mathrm{SD}=0.51)$. And the student arranges the kitchen utensils according to its function accordingly in $(\mathrm{M}=4.41, \mathrm{SD}=0.54)$. The overall weighted mean resulted in 4.45 , standard deviation of 0.57 with remarks of always and verbal interpretation of excellent. This denotes that students were able to show their technical skills with the use of tools and equipment in TLE subject in online distance learning.

Table 11. Level of Technical Skills of the Students in TLE in terms of Occupational Health and Safety

\begin{tabular}{lccc}
\hline \multicolumn{1}{c}{ STATEMENT } & Mean & SD & Remarks \\
\hline As a Students, I am able to: & 4.54 & 0.50 & Always \\
$\begin{array}{l}\text { 1. I wash my hand frequently. } \\
\text { 2. I always take vitamins. }\end{array}$ & 4.37 & 0.53 & Always \\
3. I eat nutritious food. & 4.37 & 0.48 & Always \\
$\begin{array}{l}\text { 4. I aware to the safety protocols. } \\
\text { 5. I watch news for me to become aware in the } \\
\text { present situation especially in the health news. }\end{array} \quad 4.44$ & 0.50 & Always \\
$\quad$ Grand Mean/SD & 4.44 & 0.54 & Always \\
$\quad$ Verbal Interpretation & $\mathbf{4 . 4 3}$ & $\mathbf{0 . 5 1}$ & Always \\
$\quad$ & & & Excellent \\
\hline
\end{tabular}

The table 11 above shows the result in the level of technical skills of the students in TLE in terms of occupation health and safety. Statement no. 1, "I wash hands frequently" with the $(\mathrm{M}=4.54, \mathrm{SD}=0.50)$. Statement no. 2, "I always take vitamins ", with $(\mathrm{M}=4.37, \mathrm{SD}=0.53)$. Statement no. 3, "I eat notorious food both resulted a $(\mathrm{M}=4.37, \mathrm{SD}=0.48)$. Statement no. 4, "I am aware to the safety protocols and statement no. 5, "I watch news to become aware in the present situation especially in health news, both got a $(\mathrm{M}=4.44, \mathrm{SD}=0.50)$, with the overall weighted mean of 4.43, standard deviation of 0.51 , remarks of always and verbal interpretation of excellent. The students in online distance learning were able to show their technical skills in the terms of occupational health and safety amidst the pandemic

Effect of teaching strategies in online distance learning on critical thinking skills and technical skills of the students in TLE

This data shows based on the result the effect of online distance learning in the critical thinking skills and technical skills of the students. Minitab 14 was used in computing the data gathered and treated them statistically using Linear Regression Analysis. The computed p-values were compared to the level of significance at 0.05 to determine the Effect of teaching strategies in online distance learning on the critical 


\section{EPRA International Journal of Research and Development (IJRD)}

thinking skills and technical skills of selected grade 7 and 8 students. The table shows the variables, t-value, pvalue, decision on $\mathrm{H}_{0}$ and the analysis

Table 12. Effect of teaching strategies in Online Distance Learning on the critical thinking skills as to Alertness of the students

\begin{tabular}{lcccc}
\hline \multicolumn{1}{c}{ Variables } & t-value & p-value & Decision on $\mathrm{H}_{\mathrm{o}}$ & Analysis \\
\hline $\begin{array}{l}\text { Lecture Discussion Method/ } \\
\begin{array}{l}\text { Virtual Class } \\
\text { Alertness }\end{array}\end{array}$ & 3.96 & 0.000 & Reject & Significant \\
\hline $\begin{array}{l}\text { Inquiry-based Method } \\
\text { Alertness }\end{array}$ & 2.36 & 0.024 & Reject & Significant \\
\hline $\begin{array}{l}\text { Visualization } \\
\text { Alertness }\end{array}$ & 1.10 & 0.278 & Accept & Not Significant \\
\hline $\begin{array}{l}\text { Elaboration } \\
\text { Alertness }\end{array}$ & -2.27 & .000 & Reject & Significant \\
\hline
\end{tabular}

*significant at .05 level of significance

Table 12 consists of the results on the effect of teaching strategies in Online Distance Learning in the critical thinking skills as to alertness of the selected students. The variable in the lecture discussion / virtual class results with the $(\mathrm{t}=3.96, \mathrm{p}=0.000)$ decision on is to reject the Ho and analysis of significant. The inquiry-based method with the $(\mathrm{t}=2.96, \mathrm{p}=0.024)$ the decision is to reject the Ho and analysis of significant. The visualization as to alertness got the $(\mathrm{t}=1.10 ; \mathrm{p}=0.278)$ the decision is to accept the Ho and analysis of not significant. The elaboration as to alertness resulted with the $(\mathrm{t}=-2.27, \mathrm{p}=.000)$ decision of reject Ho and has the analysis of significant. This conclude that teaching strategies in online distance learning in terms of lecture discussion, inquiry-based method and elaboration method effect the critical thinking skill of the students as to alertness, while visualization method has no significant effect on the critical thinking skill of the students as to alertness. This means that student prefer to do things with a well-structured and attainable plan.

Table 13. Effect of teaching strategies in Online distance learning on the critical thinking skills as to Flexibility of the students

\begin{tabular}{lcccc}
\hline \multicolumn{1}{c}{ Variables } & t-value & p-value & Decision on $\mathrm{H}_{\mathrm{o}}$ & Analysis \\
\hline $\begin{array}{l}\text { Lecture Discussion } \\
\text { Method/ Virtual Class } \\
\text { Flexibility }\end{array}$ & -0.16 & 0.873 & Accept & Not Significant \\
\hline $\begin{array}{l}\text { Inquiry-based Method } \\
\text { Flexibility }\end{array}$ & 5.71 & 0.000 & Reject & Significant \\
\hline $\begin{array}{l}\text { Visualization } \\
\text { Flexibility }\end{array}$ & 0.12 & 0.907 & Accept & Not Significant \\
\hline $\begin{array}{l}\text { Elaboration } \\
\text { Flexibility }\end{array}$ & -0.11 & 0.915 & Accept & Not Significant \\
\hline
\end{tabular}

Table 13 shows the results in the effect of teaching strategies in online distance learning on critical thinking as to flexibility of the selected students. The results in the lecture discussion method/ virtual class in the $(\mathrm{t}=0.16, \mathrm{p}=0.873$, accept the decision on Ho, analysis is not significant. The inquiry-based on flexibility of the students with the $(\mathrm{t}=5.71, \mathrm{p}=0.000)$ reject the decision on Ho, and analysis of significant. The Visualization as to flexibility of the students resulted in the $(\mathrm{t}=0.12, \mathrm{p}=0.907)$, the decision is to accept the Ho and analysis of not significant, Lastly, in the elaboration as to flexibility with $(\mathrm{t}=-0.11$, $\mathrm{p}$-value of 0.915$)$, accept the decision on Ho and analysis is not significant. This conclude that teaching strategies in online distance learning in terms of lecture discussion/virtual class, visualization and elaboration has no significant effect to the critical thinking of the students as to flexibility, while inquiry-based method has significant effect to the critical thinking skills of 


\section{EPRA International Journal of Research and Development (IJRD)}

the students as to flexibility. This means that students like better sharing their different ideas and ways of thinking to the discussion.

Table 14. Effect of teaching strategies in online distance learning on the critical thinking skills as to Decision Making of the students

\begin{tabular}{lcccc}
\hline \multicolumn{1}{c}{ Variables } & t-value & p-value & Decision on $\mathrm{H}_{\mathrm{o}}$ & Analysis \\
\hline $\begin{array}{l}\text { Lecture Discussion Method/ } \\
\begin{array}{l}\text { Virtual Class } \\
\text { Decision making }\end{array}\end{array}$ & 1.67 & 0.104 & Accept & Not Significant \\
\hline $\begin{array}{l}\text { Inquiry-based Method } \\
\text { Decision making }\end{array}$ & 5.25 & 0.000 & Reject & Significant \\
\hline $\begin{array}{l}\text { Visualization } \\
\text { Decision making }\end{array}$ & -0.25 & 0.803 & Accept & Not Significant \\
\hline $\begin{array}{l}\text { Elaboration } \\
\text { Decision making }\end{array}$ & -0.39 & 0.695 & Accept & Not Significant \\
\hline
\end{tabular}

The table 14 above indicates the result in the effect of teaching strategies in online distance learning on critical thinking skills as to decision making of the TLE students. In the lecture discussion method/ virtual discussion with the $(\mathrm{t}=1.67, \mathrm{p}=0.104)$ decision is to accept the Ho, analysis of not significant. The Inquirybased method as to decision making has the $\mathrm{t}$-value of $(\mathrm{t}=5.25, \mathrm{p}=0.000)$, the decision is to reject the Ho, with the analysis of significant. The visualization as to decision making with $(\mathrm{t}=-0.25, \mathrm{p}=0.803)$, the decision is to accept the Ho, with the analysis of not significant. Elaboration on decision making has the $(\mathrm{t}=-0.39, \mathrm{p}=0.695)$, the decision is to accept the Ho, the analysis is not significant. This conclude that teaching strategies in online distance learning in terms of lecture discussion,/virtual class, visualization and elaboration has no significant effect to the critical thinking skills of the students as to decision making, while-inquiry based method has significant effect to the critical thinking skills of the students as to decision making. This means that students engaged in a class with a questions or problem and strategies to develop subsequent solution and explanation.

Table 15. Effect of teaching strategies in online distance learning on technical skills of the students as to Mensuration and Calculation

\begin{tabular}{lcccc}
\hline \multicolumn{1}{c}{ Variables } & t-value & p-value & Decision on $\mathrm{H}_{\mathrm{o}}$ & Analysis \\
\hline $\begin{array}{l}\text { Lecture Discussion Method/ } \\
\begin{array}{l}\text { Virtual Class } \\
\text { Mensuration and Calculation }\end{array}\end{array}$ & 1.97 & 0.057 & Accept & Not Significant \\
\hline $\begin{array}{l}\text { Inquiry-based Method } \\
\text { Mensuration and Calculation }\end{array}$ & 2.23 & .032 & Reject & Significant \\
\hline $\begin{array}{l}\text { Visualization } \\
\text { Mensuration and Calculation }\end{array}$ & 0.22 & 0.828 & Accept & Not Significant \\
\hline $\begin{array}{l}\text { Elaboration } \\
\text { Mensuration and Calculation }\end{array}$ & -0.79 & 0.436 & Accept & Not Significant \\
\hline
\end{tabular}

Table 15 above shows the result on the effect of teaching strategies in online distance learning on technical skills of the selected student in Liliw National High School, Liliw Laguna. The results are as follows; the lecture discussion method/ virtual class as to mensuration and calculation it has the $(\mathrm{t}=1.97, \mathrm{p}=0.05)$, accept the decision on Ho, with the analysis of not significant. The inquiry-based method in mensuration and calculation has the $(\mathrm{t}=2.23, \mathrm{p}=0.32)$, decision is to reject the Ho and the analysis is significant. The visualization has the $(\mathrm{t}=0.22, \mathrm{p}=0.828)$, decision is to accept the decision in Ho with the analysis of not significant. Lastly in elaboration as to mensuration and calculation $(\mathrm{t}=-0.79, \mathrm{p}=0.436)$, the decision is to accept Ho and the analysis is not significant. This conclude that teaching strategies in online distance learning in terms 


\section{EPRA International Journal of Research and Development (IJRD)}

Volume: 6 | Issue: 6 | June 2021

- Peer Reviewed Journal

of lecture discussion,/virtual class, visualization and elaboration has no significant effect to the technical skills of the students as to mensuration and calculations, while-inquiry based method has significant effect to the technical of the students as to mensuration and calculations. This implies that students prefer to do things that allow them to build knowledge through exploration, experience and discussion.

Table 16. Effect of teaching strategies in online distance learning on the technical skills of students as to Use of tool and equipment

\begin{tabular}{lcccc}
\hline \multicolumn{1}{c}{ Variables } & t-value & p-value & Decision on $\mathrm{H}_{\mathrm{o}}$ & Analysis \\
\hline $\begin{array}{l}\text { Lecture Discussion Method/ } \\
\begin{array}{l}\text { Virtual Class } \\
\text { Use of tool and equipment }\end{array}\end{array}$ & 0.57 & 0.572 & Accept & Not Significant \\
\hline $\begin{array}{l}\text { Inquiry-based Method } \\
\text { Use of tool and equipment }\end{array}$ & 2.80 & 0.008 & Reject & Significant \\
\hline $\begin{array}{l}\text { Visualization } \\
\text { Use of tool and equipment }\end{array}$ & 0.73 & 0.467 & Accept & Not Significant \\
\hline $\begin{array}{l}\text { Elaboration } \\
\text { Use of tool and equipment }\end{array}$ & 0.48 & 0.635 & Accept & Not Significant \\
\hline
\end{tabular}

The table 16 presents the effect of teaching strategies in online distance learning on technical skills as to use of tool and equipment of the students in Liliw National High School, Liliw Laguna. The result in the lecture discussion method/ virtua lclass is $(\mathrm{t}=0.57, \mathrm{p}=0.572)$, decision is to accept the Ho and the analysis is not significant. The inquiry-based method has the $(\mathrm{t}=2.80, \mathrm{p}=0.008)$, the decision is to reject the Ho and the analysis is significant. The visualization has the $(\mathrm{t}=0.73, \mathrm{p}=0.467)$, accept the decision on Ho, the analysis is not significant. In elaboration ( $\mathrm{t}=0.48, \mathrm{p}=0.635$ ), accept the decision on Ho, and the analysis is not significant. This conclude that teaching strategies in online distance learning in terms of lecture discussion,/virtual class, visualization and elaboration has no significant effect to the technical skills of the students as use of tools and equipment, while-inquiry based method has significant effect to the technical of the students as to use of tools and equipment. This means that students learn to use tools and equipment with the aid of their teacher.

Table 17. Effect of teaching strategies in Online Distance Learning on technical skills as to Occupational health and safety

\begin{tabular}{lcccc}
\multicolumn{1}{c}{ Variables } & t-value & p-value & Decision on $\mathrm{H}_{\mathrm{o}}$ & Analysis \\
\hline $\begin{array}{l}\text { Lecture Discussion Method/ } \\
\begin{array}{l}\text { Virtual Class } \\
\text { Occupational health and safety }\end{array}\end{array}$ & 3.04 & 0.004 & Reject & Significant \\
\hline $\begin{array}{l}\text { Inquiry-based Method } \\
\text { Occupational health and safety }\end{array}$ & 1.94 & 0.060 & Accept & Not Significant \\
\hline $\begin{array}{l}\text { Visualization } \\
\text { Occupational health and safety }\end{array}$ & 0.34 & 0.734 & Accept & Not Significant \\
\hline $\begin{array}{l}\text { Elaboration } \\
\text { Occupational health and safety }\end{array}$ & -1.63 & 0.111 & Accept & Not Significant \\
\hline
\end{tabular}

Table 17 above shows the result in the effect of teaching strategies in Online Distance Learning on technical skills as to occupational health and safety of students. The statement has the result in the lecture discussion / virtual class has the $(\mathrm{t}=3.94, \mathrm{p}=0.004)$, the decision is to reject the Ho, and the analysis is significant. The inquiry-based method has the $(\mathrm{t}=1.94, \mathrm{p}=0.060)$, the decision is to accept the Ho, and the analysis is not significant. In the visualization the $(\mathrm{t}=0.34, \mathrm{p}=0.734)$, and the decision is to accept the Ho, with the analysis of not significant. The elaboration shows the result of $(\mathrm{t}=-1.63, \mathrm{p}=0.111)$, the decision is to accept the Ho and the analysis is not significant. This conclude that teaching strategies in online distance learning in terms of inquiry based method, visualization and elaboration has no significant effect to the technical skills of 
the students as to occupational health and safety, while lecture discussion/virtual class has significant effect to the technical skills of the students as to occupational. This means that students like better their teachers to deliver lecture virtually.

\section{CONCLUSION}

Drawn the results of the study, the following results are set forth;

The effect of teaching strategies in online distance learning in the critical thinking skills of the students as to alertness, flexibility and decision making has not sustained the research hypothesis; therefore; the null hypothesis was partially accepted.

In the effect of strategies in online distance learning in the technical skills of the students as to mensuration and calculation, use of tools and equipment and occupational safety has partially sustained the research hypothesis therefore the null hypothesis was also partially accepted ..

\section{RECOMMENDATION}

In the light of the findings and conclusion of the study, the following recommendations were drawn.

1. The strategies of teaching in teaching technology and livelihood education (TLE) needs to maintain and enhanced to bring out the best of the students' performance.

2. The lecture discussion in the virtual methods suggests having more engaging activities for the students to be motivated.

3. Continue to prepare for the current situation that our education system is facing today for the benefit of our students and their future.

4. The school must have continuous program implementation for LAC session or learning action cell training to develop passion in the teaching profession amidst pandemic.

5. For future researches, develop a research that could have a continuous monitoring in this study.

\section{REFERENCES}

1. Acar, O. A., \& Tuncdogan, A. (2018). Using the inquiry-based learning approach to enhance student innovativeness: a conceptual model. Teaching in Higher Education, 1-15. doi:10.1080/13562517.2018.1516636

2. Adams, N. E. (2015). Bloom's taxonomy of cognitive learning objectives. Journal of the Medical Library Association: JMLA, 103(3), 152-153. doi:10.3163/1536-5050.103.3.010.

3. Al Akashee, Bushra. (1991). The brief college student hassles scale: Development, validation, and relation with pessimism. Journal of College Student Development, 32(3), 258-264.

4. Andrew W. Kruse, Andrey S. Alenin, J. Scott Tyo (2019). Review of Visualization Methods for passive polarization imaging https://doi.org/10.1117/1.OE.58.8.082414

5. Agarwal, S., \& Kaushik, J. S. (2020). Student's Perception of Online Learning during COVID Pandemic. The Indian Journal of Pediatrics. https://doi.org/10.1007/s12098- 020-03327-7

6. Antwi-Afari, M. F., Li, H., Wong, J. K.-W., Oladinrin, O. T., Ge, J. X., Seo, J., \& Wong, A. Y. L. (2019). Sensing and warning-based technology applications to improve occupational health and safety in the construction industry. Engineering, Construction and Architectural Management. doi:10.1108/ecam-05-2018-0188

7. Assarroudi, A., Heshmati Nabavi, F., Armat, M. R., Ebadi, A., \& Vaismoradi, M. (2018). Directed qualitative content analysis: the description and elaboration of its underpinning methods and data analysis process. Journal of Research in Nursing, 23(1), 42-55. doi:10.1177/1744987117741667

8. Bačić, D., \& Fadlalla, A. (2016). Business information visualization intellectual contributions: An integrative framework of visualization capabilities and dimensions of visual intelligence. Decision Support Systems, 89, 7786. doi:10.1016/j.dss.2016.06.011

9. Bozkurt, A. \& Sharma, R. C. (2020). Emergency remote teaching in a time of global crisis due to CoronaVirus pandemic. Asian Journal of Distance Education, 15(1) https://doi.org/10.5281/zenodo.3778083

10. Brassey J, Witteloostuijn Av, Huszka C, Silberzahn T, Dam Nv (2020) Emotional flexibility and general selfefficacy: A pilot training intervention study with knowledge workers. PLoS ONE 15(10): e0237821. https://doi.org/10.1371/journal.pone.0237821

11. Catane, J. (2000). Conducting Research: A Practical Application. JMC Press Inc., 388 Quezon Avenue, Quezon City

12. Chen, James (2019). Investopedia. Technical Analysis Basic Education Skills

13. Dabbagh, R., \& Yousefi, S. (2019). A hybrid decision-making approach based on FCM and MOORA for occupational health and safety risk analysis. Journal of Safety Research. doi:10.1016/j.jsr.2019.09.021.

14. Dumas, D., Organisciak, P., Maio, S., \& Doherty, M. (2020). Four Text-Mining Methods for Measuring Elaboration. The Journal of Creative Behavior. doi:10.1002/jocb.471

15. Eun, B. (2019). The zone of proximal development as an overarching concept: A framework for synthesizing 


\section{EPRA International Journal of Research and Development (IJRD)}

Vygotsky's theories. Educational Philosophy and Theory, 51, 18-30

16. Eshetu, F., \& Assefa, S. (2019). Effects of context-based instructional approaches on students' problem-solving skills in rotational motion. EURASIA Journal of Mathematics, Science and Technology Education, 15 (2), 1-13

17. Farrel, D., Ray, K., Rich, T., Suarez, Z., Christenson, B., \& Jennigs, L. (2018). A meta - analysis of approaches to engage social work students online. Journal of Teaching in Social Work, 38(2), 183 - 197. https://doi.org/10.1080/08841233.2018.1431351Crossref Web of Science ${ }^{\circledR G o o g l e ~ S c h o l a r ~}$

18. Fernandez, R., Peralbo-Uzquiano, M., Duran-Bouza, 'M., Brenlla-Blanco, J. C., \& García-Fernandez, 'M. (2019). Virtual intervention programme to improve the working memory and basic mathematical skills in early childhood education. Revista de Psicodidactica, '24(1), 17-23. https://doi.org/10.1016/j.psicoe.2018.09.003

19. Freeman, S., Eddy, S. L., McDonough, M., Smith, M. K., Okoroafor, N., Jordt, H., \& Wenderoth, M. P. (2014). Active learning increases student performance in science, engineering, and mathematics. Proceedings of the National Academy of Sciences, 111(23), 8410- 8415. https://doi.org/10.1073/pnas.1319030111 Crossref CAS PubMed Web of Science ${ }^{\circledR}$ Google Scholar.

20. Giovannella, C. (2020). Effect induced by the COVID-19 pandemic on students' perception about technologies and distance learning. SLERD 2020, at Bucharest (on-line) http://slerd2019.uniroma2.it/paper-sessions/

21. Gerald L. Ygay Mauro Allan P. Amparado (2018) Cebu Normal University, Cebu City, Philippines Lecturediscussion Versus Inquiry-based Learning in the NCM 101 Academic Performance.

22. Hamilton, L. S., Kaufman, J.H., \& Diliberti, M. (2020). Teaching and Leading Through a Pandemic: Key Findings from the American Educator Panels Spring 2020 COVID-19 235 Educational Practices during the COVID-19 Viral Outbreak: International Perspectives Surveys. Creative Commons Attribution 4.0 International Public License. https://www.rand.org/pubs/research_reports/RRA168-2.html

23. Ji, Z., Pons, D. J., \& Pearse, J. (2020). Integrating occupational health and safety into plant simulation. Safety Science, 130, 104898. doi:10.1016/j.ssci.2020.104898

24. Lim, C. D. (2016). Exploring educational platforms and community behavior to support DLSU online blended learning initiative, http://xsite.dlsu.edu.ph/conferences/dlsu-research-congress-proceedings/2016/GRC/GRCLLI-002.pdf

25. Linneman, Judith A. (2018) Share, Show and Tell: Group Discussion or Simulation Versus Lecture Teaching Strategies in a research method course. September 20, 2018 Research Article Texas A\&M University, College Station, TX, USA https://doi.org/10.1177/0092055X18799405

26. Masa, Juan Arías et al. (2019) Synchronous Virtual Classrooms in Problem-Based Learning to Mentor and Monitor Students in Higher Education Springer Nature Switzerland AG 2019133 E. Smyrnova-Trybulska et al. (eds.), Universities in the Networked Society, Critical Studies of Education 10, https://doi.org/10.1007/978-3030-05026-9_8

27. McCoy, Charles Allan. (2017). "Playing Goffman's Information Game: A Classroom Activity Involving Student Interactions." Teaching Sociology 45(3):260-68.

28. McLaren, Kristy (2019). Why Technology skills so important to today's students? https://www.immerse.education/resource/why-are-tech-skills-so-important-to-todays-students/

29. Neneh, B. N. (2019). From entrepreneurial alertness to entrepreneurial behavior: The role of trait competitiveness and proactive personality. Personality and Individual Differences, 138, 273-279. doi:10.1016/j.paid.2018.10.020

30. Ngurukwem, C. C., \& Ede, G. (2017). Lifelong learning in the vanguard for reskilling. National Council for Adult Education Journal, 22(1), 232-237.

31. Ni, A. Y. (2016). Comparing the effectiveness of classroom and online learning: Teaching research methods. Journal of Public Affairs Education, 19(2), 199-215

32. Nnebedum, C., Obuegbe, A. S., \& Nwafor, H. E. (2021). Assessment of schools' reopening after COVID-19 closures. International Journal on Studies in Education (IJonSE), 3(2), 86- 91. Vol 3, No 2, 86-91, 2021 ISSN: 2690-7909

33. Paudel, P. (2020). Online education: Benefits, challenges and strategies during and after COVID-19 in higher education. International Journal on Studies in Education (IJonSE), 3(2), 70-85. https://doi.org/10.46328/ijonse.32

34. Peralbo-Uzquiano, M., Fernández-Abella, R., Durán-Bouza, M., Brenlla-Blanco, J.-C., \& Cotos-Yáñez, J.-M. (2020). Evaluation of the effects of a virtual intervention programme on cognitive flexibility, inhibitory control and basic math skills in childhood education. Computers \& Education, 159, 104006. doi:10.1016/j.compedu.2020.104006

35. Resurreccion, P. F. (2018). Understanding the blended learning readiness of students of a State University in Southern Philippines.Editorial Staff, 367

36. Rolffs JL, Rogge RD, Wilson KG. (2018) Disentangling components of flexibility via the hexaflex model: Development and validation of the Multidimensional Psychological Flexibility Inventory (MPFI). Assessment. 2018; 25(4):458-82. https://doi.org/10.1177/1073191116645905 PMID: 27152011

37. Schneider, D. W. (2018). Alertness and cognitive control: Is there a spatial attention constraint? Attention, Perception, \& Psychophysics. doi:10.3758/s13414-018-1613-9

38. Schönberg, S., Asher, R., Stewart, S., Fenwick, M. J., Ashton, L., Bucher, T., Shrewsbury, V. A. (2020). 


\section{EPRA International Journal of Research and Development (IJRD)}

Development of the Home Cooking EnviRonment and Equipment Inventory Observation form (HomeCookERITM): An Assessment of Content Validity, Face Validity, and Inter-Rater Agreement. Nutrients, 12(6), 1853. doi:10.3390/nu12061853

39. Sevilla, Consuelo G. et. al. (2007). Research Methods. Rex Printing Company. Quezon City'

40. Silvennoinen, M.; Mikkonen, J.; Manu, M.; Malinen, A.; Parviainen, T.; Vesisenaho, M. (2019). New Methods Deepening Understanding of Students' Experiences and Their Relation to Physiological Alertness Variations During Learning. In Gómez Chova, L.; López Martínez, A.; Torres, Candel (Eds.) EDULEARN19 Proceedings. 11th International Conference on Education and New Learning Technologies, EDULEARN Proceedings. IATED Academy, 9219-9228. DOI: 10.21125/edulearn.2019.2290

41. S. Zollmann, R. Grasset, T. Langlotz, W. H. Lo, S. Mori and H. Regenbrecht. (2017). "Visualization Techniques in Augmented Reality: A Taxonomy, Methods and Patterns," in IEEE Transactions on Visualization and Computer Graphics, doi: 10.1109/TVCG.2020.2986247.

42. Terry, Richard, et al,.(2019). Chapter 21: Successful teaching in virtual classrooms 15 October 2019, Monograph Chapter : DOI: https://doi.org/10.4337/9781788975087.00035 pages: 211-221 (11 total) Collection: Business 2019

43. Tambunan, H. (2018). Impact of Heuristic Strategy on Students' Mathematics Ability in High Order Thinking. International Electronic Journal of Mathematics Education, 13(3), 321-328. https://doi.org/10.12973/iejme/3928

44. Tatiana Markova, Irina Glazkova and Elena Zaborova. (2017). Quality Issues of Online Distance Learning Ural State University of Economics, 62, 8 Marta St, Yekaterinburg, 620144, Russia, doi: 10.1016/j.sbspro.2017.02.043

45. Udegbunam, J. M., \& Koledoye, L. U. (2017). Enhancing employability through training and lifelong learning. National Council for Adult Education Journal, 22(1), 233-246.

46. Wartono Wartono, Yohana Fransiska et. al. (2019) Volume 8, no. 2, March 2019 : Inquiry-Scaffolding Learning Model: It's Effect on Critical Thinking Skills and Conceptual Understanding https://doi.org/10.24042/jipfalbiruni.v8i2.4214 